\title{
Epithermal gold and massive sulphide mineralisation in oil impregnated Palaeogene volcanic rocks of Ubekendt Ejland, West Greenland
}

\author{
Stefan Bernstein and Christian Knudsen
}

The discovery in 2002 of a gold mineralised quartz-carbonate vein at Ubekendt Ejland, central West Greenland, yielding $0.6 \mathrm{ppm}$ Au over $0.7 \mathrm{~m}$, led to a reconnaissance sampling project in summer 2003. Most of the accessible quartz-carbonate veins on the south-east coast of the island (Figs 1, 2) were sampled during boat-supported field work. Massive sulphide mineral deposits $(\mathrm{Fe}-\mathrm{Zn}-\mathrm{Pb})$ were located in the centre of brecciated quartz-carbonate vein systems at several places along the south and south-east coast of the island, and gold anomalies mainly associated with the occurrence of the massive sulphides were identified. Pervasive hydrothermal alteration of the volcanic wall rocks surrounds the quartz-carbonate vein systems, which comprise low-temperature mineral assemblages dominated by dolomite and veined by chalcedony and fibrous silica. Evidence of oil migration into volcaniclastic rocks prior to the intense hydrothermal activity was found in several places in the form of organic carbon, interpreted to be pyrobitumen, that infills pores and cavities in hyaloclastites.

\section{Geological setting}

Ubekendt Ejland comprises early Palaeogene volcanic and intrusive rocks (Fig. 1; Drever \& Game 1948; Larsen 1977a, b).
Fig. 1. Geological map of Ubekendt Ejland. Most quartz-carbonate veins (red lines) visited in 2003 are located from $5 \mathrm{~km}$ east of Nuunngutak to $7 \mathrm{~km}$ west of Qeqertalik. Modified from Larsen (1977a, b). Spot heights (e.g. 420) are in metres.

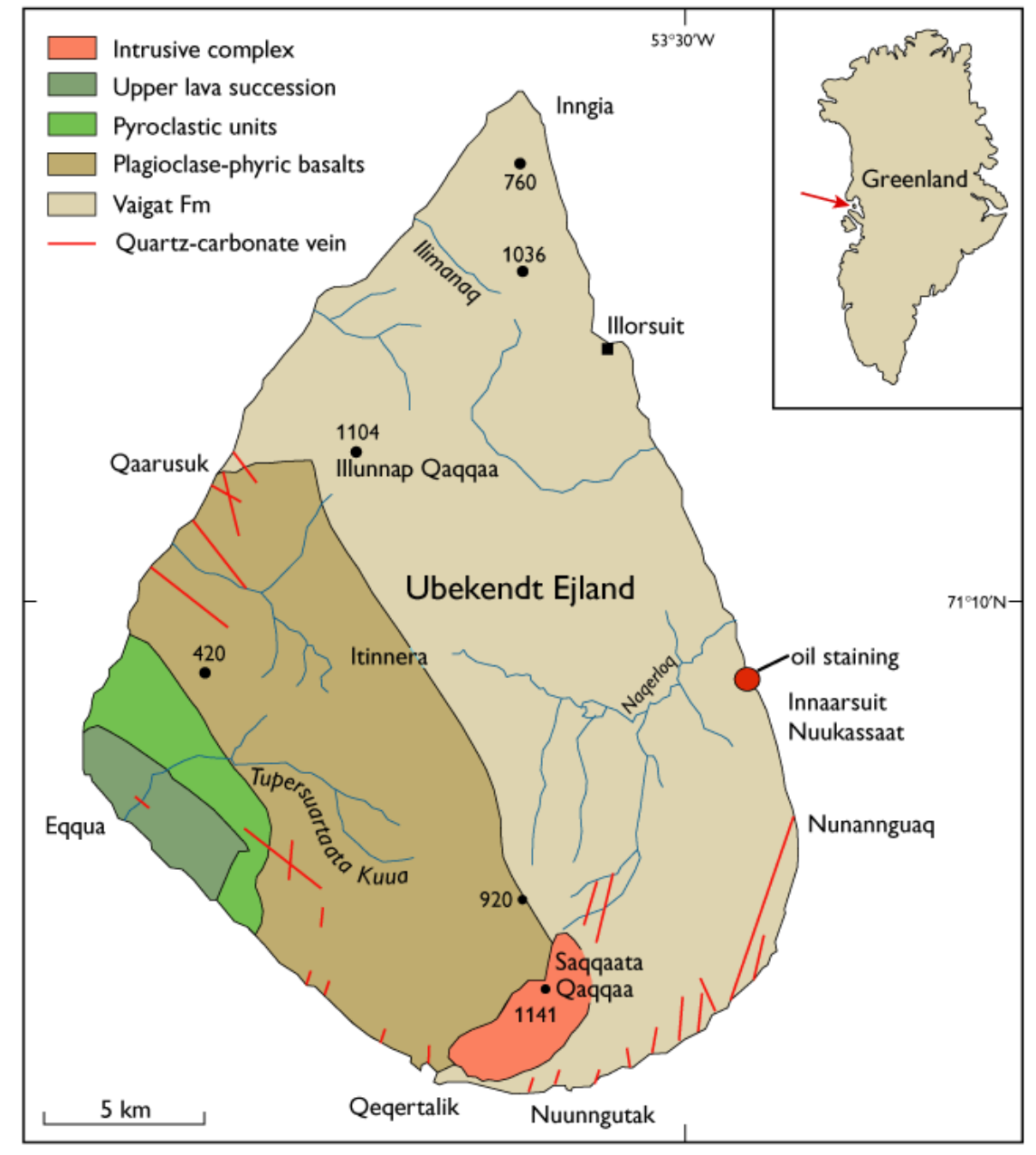




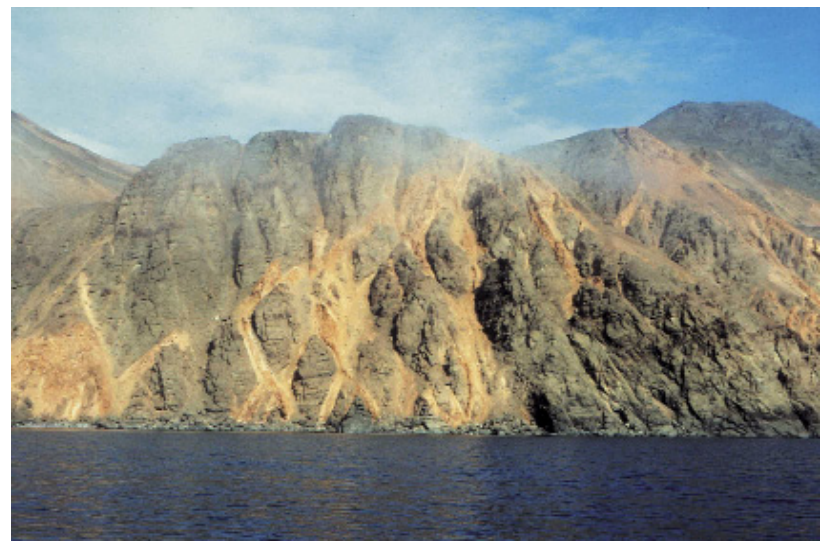

Fig. 2. Quartz-carbonate vein systems cutting picritic lava flows of the Vaigat Formation, about $3 \mathrm{~km}$ east of Nuunngutak (Fig. 1). Height of cliff about $150 \mathrm{~m}$. The orange-buff coloured patterns include both the quartzcarbonate veins and their alteration halos, typically 2-10 m wide.

Most of the island consists of picritic and olivine-phyric lavas, hyaloclastites and volcanic breccias, assigned to the Vaigat Formation (Fig. 1). The Vaigat Formation succession dips $20-30^{\circ}$ to the west and is overlain by plagioclase-phyric lavas, pyroclastic units and an upper lava succession including alkaline basalts (Larsen 1977b). A mafic-felsic intrusive complex, that includes layered gabbros and fine-grained granite, is found at Saqqaata Qaqqaa in the southern part of the island.

The quartz-carbonate veins are particularly abundant in the south-eastern part of the island, but veins also occur close to the south-west coast, and on the north-west coast at Qarusuk (Fig. 1). Most veins on the south-eastern coast can be traced for a few kilometres northwards until they are hidden beneath Quaternary glacial deposits. One vein system has been traced for $6 \mathrm{~km}$ along strike. The highest density of vein systems occurs along a $5 \mathrm{~km}$ long stretch of the coast east of Nuunngutak.

\section{Quartz-carbonate veins}

Some vein systems appear to be developed as relatively welldefined planar structures that extend for some distance along strike, judging from the orange-buff outcrop coloration. In other cases, the veins form complex anastomosing systems, where sets of veins - often four or more - follow irregular trends and join upwards (Fig. 2). In general, the vein systems are subvertical. It is unclear whether the vein systems were formed during one or several events, although at several locations the veins exhibit evidence of distinct stages of brecciation and mineralisation (see below). Samples were taken up to about $5 \mathrm{~km}$ west of the intrusive complex at Saqqaata

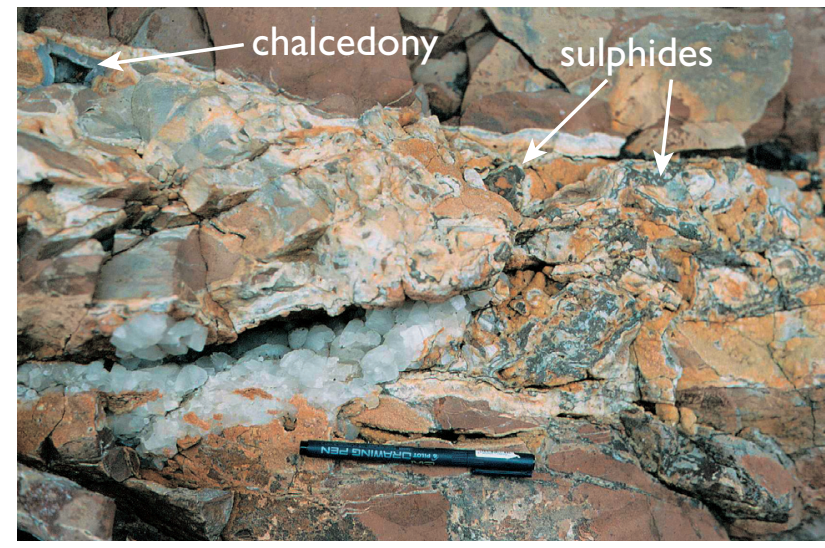

Fig. 3. A $20 \mathrm{~cm}$ thick quartz-carbonate vein in an altered dyke, $6 \mathrm{~km}$ west of Qeqertalik (Fig. 1). The vein shows several stages of brecciation, with fragments of banded dolomite overgrown with pyrite. Some cavities are lined with chalcedony, while others are lined with coarse calcite crystals. Pen is $15 \mathrm{~cm}$ long.

Qaqqaa, but no significant changes in mineralisation assemblages or structures were observed.

The quartz-carbonate veins on Ubekendt Ejland typically consist of banded carbonates with centres filled by quartz or carbonate. Thin $(<1 \mathrm{~mm})$ cross-cutting veins filled with quartz and/or fibrous silica also occur. The banded carbonates are medium- to fine-grained and some veins also have coarsegrained centres with carbonate crystals up to $20 \mathrm{~mm}$ across (Fig. 3). The outer margins of the veins are often intensely brecciated, showing a mixture of carbonate and quartz crystals and fragments, including fragments of chalcedony, set in a very fine-grained matrix of ground carbonate. The matrix sometimes shows signs of recrystallisation. Carbonate is predominantly dolomite, and grades into ankerite. Some quartzcarbonate veins exhibit later sulphide mineralisation (see below) lining late fractures and veins (Fig. 3). The late fracturing can be extensive and has resulted in brecciation zones within the quartz-carbonate veins. The latest veining and mineralisation stage resulted in the formation of chalcedony veins that are usually 1-2 mm thick, but chalcedony commonly occurs in cavities and vein centres within massive sulphides. In places, the chalcedony grades into coarser-grained quartz $(0.5 \mathrm{~mm})$. Vugs filled with fibrous quartz, probably replacing amorphous sillica, are also common.

\section{Sulphide and gold mineralisation}

In the larger quartz-carbonate veins, the sulphide mineralised fractures and breccias may be up to $15 \mathrm{~cm}$ in width and 40 $\mathrm{cm}$ long and comprise semi-massive to massive sulphides. In brecciated quartz-carbonate veins, pyrite and other sulphide minerals are euhedral or subhedral and fine-grained, while in 
Fig. 4. Upper portion of altered hyaloclastite, some $3 \mathrm{~m}$ from a quartz-carbonate vein. The black matrix between the lithic fragments is organic carbon, which also fills fine cracks in the host rock. To the right is seen a subset of thin carbonate veins. Pencil is $15 \mathrm{~cm}$ long. About $4 \mathrm{~km}$ east of Nuunngutak.

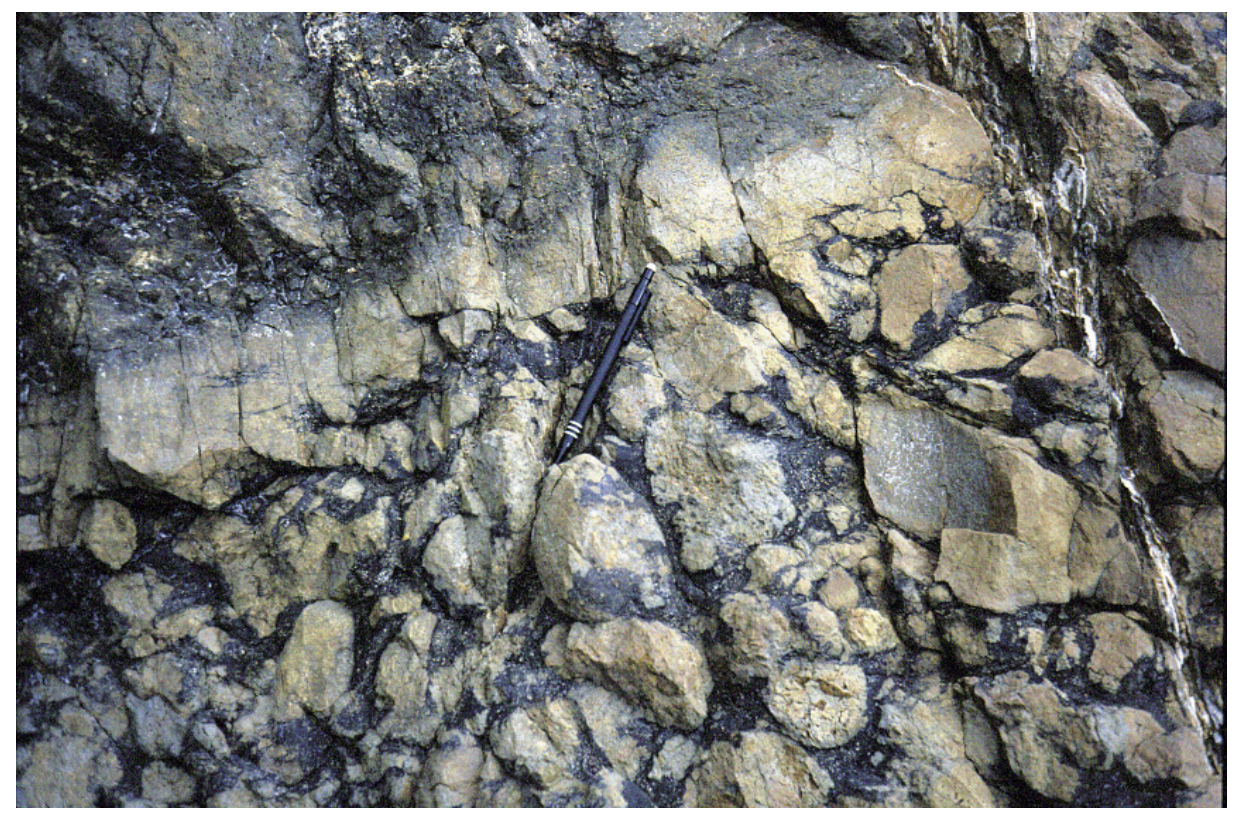

the massive sulphides, pyrite, pyrrhotite and sphalerite are subhedral and coarse-grained, most often enclosing other sulphides such as galena, arsenopyrite, millerite, pentlandite and chalcopyrite. In most vein systems, the sulphides occur as veins and in the brecciated matrix within the quartz-carbonate veins, but disseminated sulphides also occur in the altered wall rocks. Fresh sulphides have only been found in coastal outcrops, while elsewhere they are extensively altered to limonite.

Massive sulphide bodies comprise mainly pyrrhotite or pyrite, sphalerite, galena, arsenopyrite and native silver. Gold has not been seen in thin section, but samples of the massive sulphides contain up to $1300 \mathrm{ppb}$ Au and $110 \mathrm{ppm} \mathrm{Ag}$, with $3.8 \mathrm{wt} \% \mathrm{~Pb}$ and $2.2 \mathrm{wt} \% \mathrm{Zn}$. The gold appears to reside within the sulphide-mineralised vein centres.

\section{Alteration of wall rocks}

The igneous host rocks are lava flows, volcaniclastites, hyaloclastites and basaltic dykes, all of which have suffered extensive hydrothermal alteration adjacent to the quartz-carbonate veins. The alteration halos may extend up to tens of metres, but more usually are in the range of 2-5 m on either side of the vein system. Veins that follow older thick basaltic dykes often only show hydrothermal alteration in a narrow (1-2 m) zone adjacent to the vein, while the remaining dyke retains its igneous mineral assemblage.

At one location, a hyaloclastite unit is cut by a vertical, $2 \mathrm{~m}$ thick basaltic dyke. The eastern dyke contact is cut by a parallel quartz-carbonate vein system, and alteration extends to the centre of the dyke. On the east side of the vein, alteration within the hyaloclastite host rock extends for about 8-10 m. The unaltered part of the basaltic dyke contains sparse, fresh clinopyroxene phenocrysts set in a groundmass of finegrained plagioclase, clinopyroxene and $\mathrm{Fe}-\mathrm{Ti}$ oxide grains. Intersticies are filled with sericite, and vesicles with chalcedony, carbonate and illite/phengite. In the altered part of the dyke, plagioclase laths in the groundmass are still visible, but are invariably altered to sericite. Former clinopyroxene phenocrysts are replaced by fine-grained yellow clay minerals, and bands of fine-grained euhedral pyrite cross-cut the rock, together with thin (50 micron) veins of carbonate or chalcedony. Chemical analyses demonstrate that the alteration has resulted in the loss of $\mathrm{SiO}_{2}, \mathrm{MgO}, \mathrm{CaO}, \mathrm{Na}_{2} \mathrm{O}, \mathrm{Sr}$ and $\mathrm{Ba}$, and in an increase in $\mathrm{FeOtotal}, \mathrm{K}_{2} \mathrm{O}, \mathrm{Ni}, \mathrm{Rb}, \mathrm{Pb}$ and volatiles. Other elements appear unaffected by the alteration; these include $\mathrm{Ti}, \mathrm{Al}, \mathrm{P}$, the transition metals, $\mathrm{Zr}$ and the rare earth elements. These changes reflect the dissolution of igneous silicates and growth of hydrous phyllosilicates, carbonate and pyrite. We deduce that the added volatiles must include $\mathrm{H}_{2} \mathrm{O}, \mathrm{CO}_{2}$ and $\mathrm{S}$.

\section{Trace of oil on Ubekendt Ejland}

Evidence of oil migration into the onshore Palaeogene volcanic rocks is common in central West Greenland (BojesenKoefoed et al. 1999). On the east coast of Ubekendt Ejland (Fig. 1), minor oil staining has earlier been reported at the contact of a dyke (Christiansen et al. 1998). During field work in 2003, several localities with quartz-carbonate veins and alteration zones on the south-east coast of Ubekendt Ejland were found to bear evidence of oil migration into the 


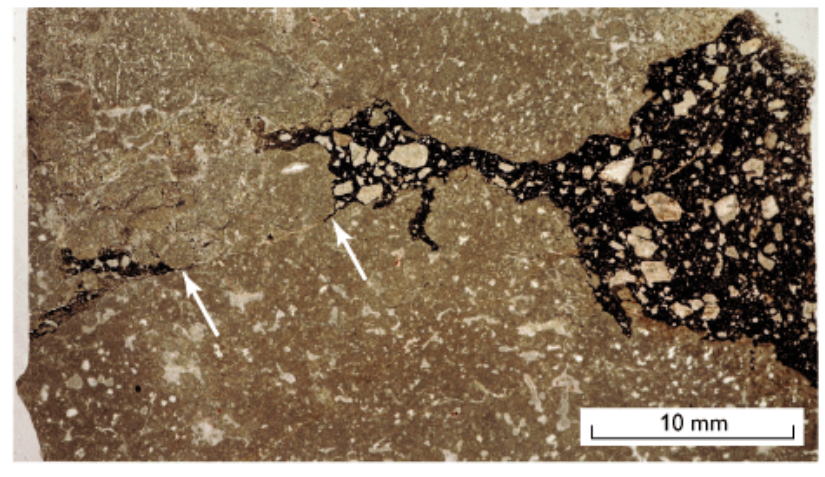

Fig. 5. Thin section of sample from locality in Fig. 4 (plane-polarised light). The dark matrix contains lithic fragments of varying size and of a similar composition to the host rock. Note the fine veins (arrowed) of dark carbon-rich material extending into the altered hyaloclastite.

volcanic rocks. At one location, this is manifested by the patchy development of black staining in altered hyaloclastic rocks (Fig. 4). In thin section, organic carbon occurs as almost opaque material enveloping lithic fragments identical to the surrounding altered hyaloclastite (Fig. 5). Analysis of the rock material yielded $1.25 \mathrm{wt} \%$ organic carbon, 2.89 $\mathrm{wt} \%$ carbon and $0.14 \mathrm{wt} \%$ sulphur. These patchy zones in the hyaloclastites are interpreted to be remnants of oil (pyrobitumen) that migrated into the volcanic rocks and filled pore space in the hyaloclastites. In this case the migration of oil occurred some time before the intense hydrothermal alteration associated with the emplacement of the quartz-carbonate vein systems. Prolonged exposure to elevated temperatures has caused thermal alteration of the oil to leave pyrobitumen as the solid residue. Assuming a density of the pyrobitumen of about $1 \mathrm{~g} / \mathrm{cm}^{3}$, the $1.25 \mathrm{wt} \%$ carbon corresponds to about 3 vol.\% organic carbon in the rock, which in turn would represent $10 \%$ of the original volume of oil. An inferred 30 vol.\% porosity in the matrix of the hyaloclastites appears likely, either reflecting primary porosity or attained by dissolution of primary pore fillings prior to the invasion of oil.

\section{Conclusion}

The presence of chalcedony and fibrous silica possibly replacing amorphous silica suggest that the quartz-carbonate veins formed at a shallow level in hydrothermal conduits. The quartz-carbonate veins are similar to epithermal $\mathrm{Au}$-rich vein mineralisations described from other volcanic terrains associated with organic-rich sediments, in terms of geological setting, vein mineralogy, alteration of wall rocks and the evidence of migration of hydrocarbons (see e.g. Sketchley \& Sinclair 1991; Sherlock \& Lehrman 1995; Sillitoe et al. 2002). The vein mineralogy and alteration assemblage further suggest the mineralisation is a low sulphidation type (e.g. Bonham 1988). The presence of Fe-Pb-Zn sulphides in several veins may indicate that the sampled level of the veins is below that of precious metal deposition, that according to the model of Buchanan (1981) would appear above that of base metal sulphides. Our findings suggest there is a potential for economic precious metal mineralisation on Ubekendt Ejland.

\section{References}

Bojesen-Koefoed, J.A., Christiansen, F.G., Nytoft, H.P. \& Pedersen, A.K 1999: Oil seepage onshore West Greenland: evidence of multiple source rocks and oil mixing. In: Fleet, A.J. \& Boldy, S.A.R. (eds): Petroleum geology of Northwest Europe: Proceedings of the 5th conference, 305-314. London: Geological Society.

Bonham, H.F. 1988: Models for volcanic-hosted epithermal precious metal deposits. In: Schafer, R.W., Cooper, J.J. \& Wikre, P.G. (eds): Bulk mineable precious metal deposits of the western United States, 259-272. Reno: Geological Society of Nevada.

Buchanan, L. 1981: Precious metal deposits associated with volcanic environments in the southwest. AR Geological Society Digest 14, 237-262.

Christiansen, F.G., Boesen, A., Bojesen-Koefoed, J.A., Dalhoff, F., Dam, G., Neuhoff, P.S., Pedersen, A.K., Pedersen, G.K., Stannius, L.S. \& Zinck-Jørgensen, K. 1998: Petroleum geological activities onshore West Greenland in 1997. Geology of Greenland Survey Bulletin 180, 10-17.

Drever, H.I. \& Game, P.M. 1948: The geology of Ubekendt Ejland, West Greenland. Meddelelser om Grønland 134(8), 34 pp.

Larsen, J.G. 1977a: Fieldwork on Ubekendt Ejland in the Tertiary basalt province of West Greenland, 1971 and 1973. Rapport Grønlands Geologiske Undersøgelse 79, 35-44.

Larsen, J.G. 1977b: Transition from low potassium olivine tholeiites to alkali basalts on Ubekendt Ejland. Meddelelser om Grønland 200(1), $42 \mathrm{pp}$.

Sherlock, R.L. \& Lehrman, N.L. 1995: Occurrences of dendritic gold at the McLaughlin Mine hot-spring gold deposit. Mineralium Deposita 30, 323-327.

Sillitoe, R.H., Cooper, C., Sale, M.J., Soechting, W., Echavarria, D. \& Gallardo, J.L. 2002: Discovery and geology of the Esquel low-sulphidation epithermal gold deposit, Patagonia, Argentina. Society of Economic Geologists, Special Publication 9, 227-240.

Sketchley, D.A. \& Sinclair, A.J. 1991: Carbonate alteration in basalt, Total Erickson gold mine, Cassiar, northern British Columbia, Canada. Economic Geology 86, 570-587. 